University of Nebraska - Lincoln

DigitalCommons@University of Nebraska - Lincoln

2020

\title{
White Women Who Lead: God, Girlfriends, and Diversity Projects in a National Evangelical Ministry
}

Kelsy Burke

Amy McDowell

Follow this and additional works at: https://digitalcommons.unl.edu/sociologyfacpub

Part of the Family, Life Course, and Society Commons, and the Social Psychology and Interaction Commons

This Article is brought to you for free and open access by the Sociology, Department of at DigitalCommons@University of Nebraska - Lincoln. It has been accepted for inclusion in Sociology Department, Faculty Publications by an authorized administrator of DigitalCommons@University of Nebraska - Lincoln. 


\title{
White Women Who Lead: God, Girlfriends, and Diversity Projects in a National Evangelical Ministry
}

\author{
Kelsy Burke ${ }^{1}$ and Amy McDowell ${ }^{2}$ \\ 1 Department of Sociology, University of Nebraska-Lincoln, Lincoln, NE \\ 2 Department of Sociology and Anthropology, University of Mississippi, Oxford, MS \\ Corresponding author: Kelsy Burke, University of Nebraska-Lincoln, Department of Sociology, \\ 742 Oldfather Hall, Lincoln, NE 68588-0324, USA; email kburke@unl.edu \\ Note - This article is equally coauthored.
}

\begin{abstract}
A robust body of literature has used feminist analysis to study white evangelical women in the United States, but few of these studies have addressed the reproduction of racial inequality. Beginning with the assumption that women-led evangelical ministries are racialized organizations, the authors examine the relationship between racial and gender ideologies and the messages of white evangelical women leaders at the IF:Gathering, a popular annual Christian women's conference in the United States. On the surface, the women who lead IF embody a contradiction: they support the conservative gender ideology of evangelicalism while challenging this religious tradition by encouraging all Christian women, regardless of race, to act as leaders within their communities. However, the authors' in-depth content analysis of livestreamed and video-recorded conference sessions reveals that the mostly white speakers at IF use race to credential their leadership. Speakers draw from a mixture of racial and gender ideologies to stress the importance of telling diverse "girlfriends" about Jesus and rescuing women of color "in the trenches" (those who
\end{abstract}

Published in Sociology of Race and Ethnicity, 2020, 15pp

doi: $10.1177 / 233264922090375$

Copyright ( 2020 American Sociological Association; published by SAGE Publications.

Used by permission. 
are from the global South or living in U.S. cities) from poverty or sexual exploitation. The findings reveal how potentially progressive and empowering messages at a women-led evangelical organization limit the definition and scope of women's leadership and reinforce the white patriarchal status quo.

Keywords: race, racism, religion, whites, gender, women

White women-led evangelical ministries offer a rich case for sociologists of race and ethnicity to understand how white American women deploy gendered racial ideologies to navigate the constraints of conservative institutions. In the United States, evangelical Christianity (by which we mean mostly white faith groups that share beliefs in repentance of sin, salvation through Jesus Christ alone, and a "high view" of biblical scripture; Putnam and Campbell 2010) tends to support an ideology of gender complementarianism, which is the belief that God created men to be leaders and women to be caretakers, helpers, and nurturers (Gallagher 2003; Griffith 1997; Ingersoll 2003). Whereas white men are presumed capable of leading without any caveat, white women's positions tend to be limited to leading over other women and children (Bowler 2019). Yet despite imbalances in formal leadership roles, previous research has shown that women have been central to influencing the activities and trajectories of many conservative Christian traditions (Cochran 2005; Higginbotham 1993). In this article, we define leadership broadly as the capacity to influence others (Thompson 2013) and ask, How do race and gender inform how evangelical women talk about their influence, whom they can lead, and how they can lead in ministry? To answer this question, we present a case study of one of the largest Christian women's conferences in the United States (Beaty 2017), the annual IF:Gathering.

IF, provocatively but vaguely titled, is the name of a national nonprofit evangelical ministry promoting the idea that Christian women should be leaders in "discipleship," spreading the gospel and living according to God's word. IF was founded by Jennie Allen, a white evangelical author and blogger who, on her personal Web site, describes her husband and their four children as "most" of her life before clarifying that, "I love them ... but I also love and believe in this generation of women." To put her belief in women into practice, Jennie describes an "army of women" who helped her launch the annual IF:Gathering, a large and flashy two-day conference that has been live-streaming 
from Austin or Dallas, Texas, since 2014. Conference sessions include small-group discussions about women's friendships, racial reconciliation, and community, along with live talks by mostly white evangelical superstars such as Jen Hatmaker, a Christian author and HGTV star, and Kay Warren, wife of Pastor Rick Warren and cofounder of Saddleback Church. The conference also plays prerecorded videos featuring other nonprofit ministries, local groups called IF:Table and IF:Local, and commercials for the online IF ministry store that carries Bible study materials, Christian books, T-shirts, and jewelry.

Using qualitative content analysis of video recordings from four years of the conference (between 2015 and 2018, totaling 98 codable sessions), we study how IF women define and promote the leadership of Christian women on an international stage that reaches hundreds of thousands of women. We are interested in IF for three primary reasons. First, the IF:Gathering has a robust online presence and has been described as the largest Christian women's conference in the United States (Beaty 2017). IF has more than 140,000 social media followers on Facebook and Twitter and more than 100,000 estimated viewers at each annual conference. In 2015, IF:Gathering organizers reported a live audience in Austin of 2,000 and a live-streaming audience of 110,000 . In 2018, we independently counted and mapped nearly 2,000 local viewing locations that livestreamed that year's annual gathering (see Figure 1). Studying a conference of this scale is an important step in understanding how white evangelical women in the twentyfirst century maintain, transform, or resist the racial and gender status quo of their religion. Second, the IF:Gathering tackles women's leadership head on: it is an independent ministry led entirely by women (as opposed to being connected to a parent church or organization), and it describes women's potential as "leaders" explicitly, even holding a conference smaller than the IF:Gathering called IF:Lead. Because evangelicals must negotiate women's leadership alongside religious beliefs about gender roles, it is important to understand how an organization that places women's leadership front and center also lays claim to a conservative evangelical identity that is grounded in whiteness (Bracey and Moore 2017; Burke, Moon, and Tobin forthcoming; Perry 2012). Third, the IF:Gathering reflects the rise of women's ministries groups that gather to watch and learn from evangelical female celebrities who author Bible studies and self-help books (Bowler 2019; Burke and McDowell 2012). Analyzing the performance of evangelical 


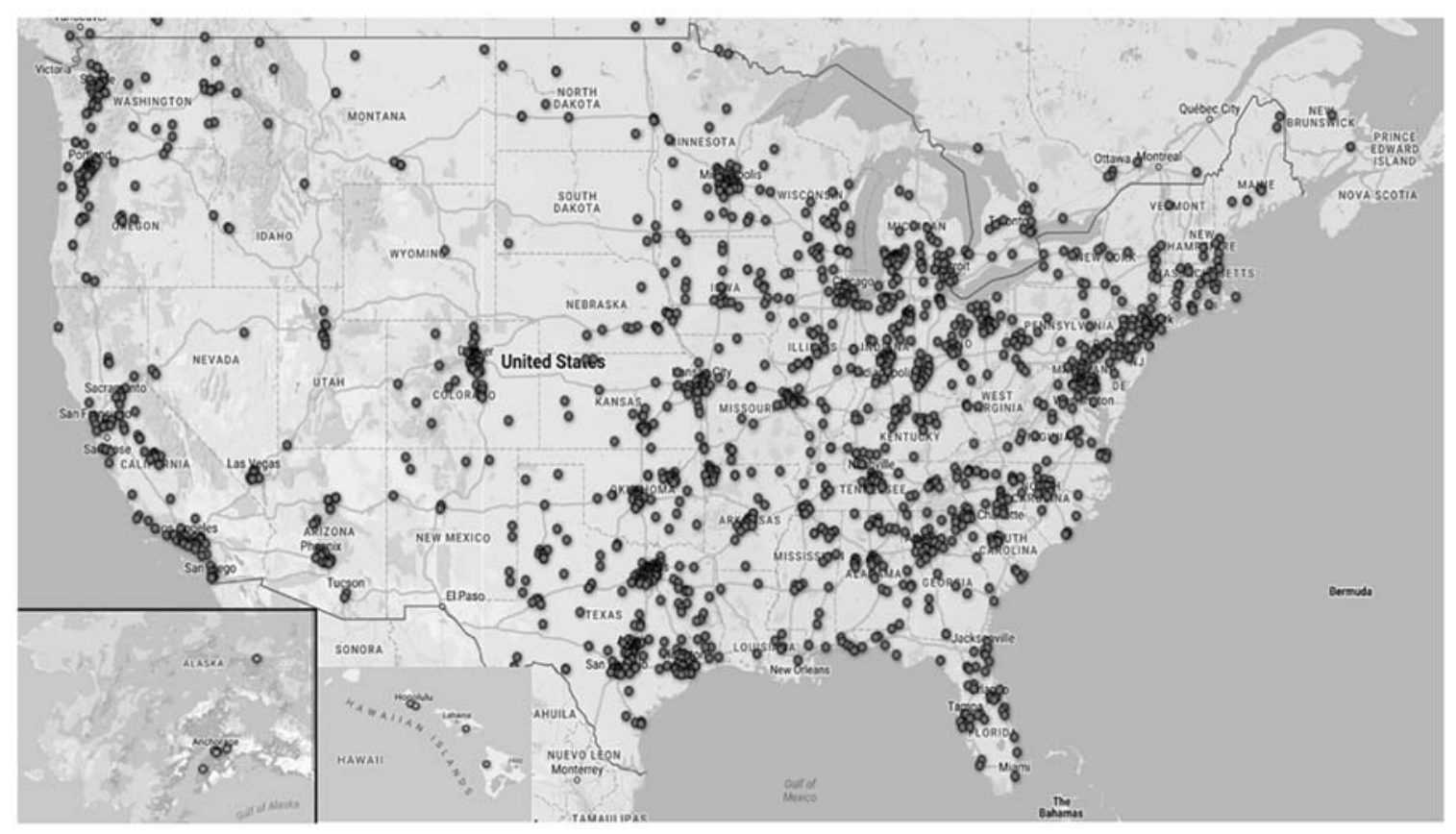

Figure 1. U.S. map of 1,878 IF:Local viewing places for the 2018 IF:Gathering. Source: https://register.ifgathering.com/if-local.

female celebrities can open up new questions about how women are shaping conservative evangelicalism, and thus the American political landscape, more broadly.

In this article, we show that messages presented at the annual IF:Gathering draw on a combination of racial and gender ideologies to promote the idea that white Christian women are capable of leading others in evangelical ministry. First, we find that IF women transform white feminine gender norms within evangelical Christianity into a tool for leadership rather than a constraint. IF:Gathering speakers align themselves with a conservative gender ideology by strategically downplaying their positions of leadership, insisting that God is ultimately in charge. We illustrate how this emphasis on women's relationships with God, despite appearing race neutral, exemplifies a color-blind racist ideology (Bonilla-Silva 2015), because white women, not women of color, benefit from its language. When IF speakers assert that "God is in control of my life and therefore I can lead," they ignore the structural conditions that privilege whiteness and assert that an all-loving God, not a white-dominated religious institution, is the one making decisions about who leads. Second, IF speakers racialize 
leadership by emphasizing that women should form gospel-centered friendships with women across racial groups. These speakers draw from a "diversity ideology" (Embrick 2011) that attempts to include women of color but still prioritizes white women's voices throughout the conference. Third, the mostly white speakers at IF emphasize "diversity projects" to present leadership as white women changing the lives of marginalized people, typically by "helping" people of color who are living in poor urban neighborhoods and/or the global South. Through a combination of these racialized and gendered messages, IF voices the idea that (mainly) white women are called by God to lead white women and women of color within evangelicalism. These findings suggest that the IF:Gathering is an example of how racial and gender ideologies blend together to preserve "inequality regimes" (Acker 2006) in ways that serve the interests of white women while protecting the structure of the white male-dominated religious traditions of which it is a part.

\section{Racial Ideologies}

A qualitative analysis of the messages at the IF:Gathering provides an empirical example of how evangelical women's ministries reflect and contribute to racial ideologies or the socially shared beliefs that benefit the dominant group about the meaning of race and the role of race in social interactions (Bonilla-Silva 2016; Burke 2017; GolashBoza 2016). Treating IF as an organization, or meso-level structure, within evangelical Christianity, we assume that it is inherently racialized whereby whiteness credentials individuals within the organization to take on leadership roles, access resources, and exhibit high degrees of agency (Ray 2019). Ray (2019) identified both material resources and shared beliefs (what he called "schemas" and others have called "ideologies") as the racialized components of organizations. Our analysis of IF offers an example of how racial ideologies operate as a set of discourses presented in mediated venues that reach wide audiences, (e.g., lectures, books, films, television) (Collins 2004; GolashBoza 2016; Nilsen and Turner 2014).

A large body of sociological research has traced the development and dominance of "covert" rather than "overt" racial ideologies in post-civil rights America (Bobo, Kluegel, and Smith 1997; Bonilla- Silva 
2015). Considerable attention has been paid to "color blindness," a racial ideology whereby individuals (usually, but not always, whites) mask racial inequalities by denying or avoiding racial differences through a variety of discursive strategies (Bonilla-Silva 2015; Burke 2017; Manning, Hartmann, and Gerteis 2015). In his now classic study, BonillaSilva (2015) found that most whites deny having racist thoughts or prejudices but simultaneously reinforce racial stereotypes, minimize the prevalence of racial discrimination, and justify racial disparities through a variety of colorblind frames, including references to raceneutral concepts of freedom, equality, and choice.

Drawing from and expanding on Bonilla-Silva (2015), many empirical studies have confirmed the prevalence of color blindness, sometimes alongside more race-conscious ideologies. Meghan Burke (2012), for example, found that white city residents used language that was "color-blind" (e.g., using personal preference to explain residential segregation) and that simultaneously celebrated racial diversity within neighborhoods. "Diversity ideology" has been analyzed by sociologists of race in a number of settings, including corporations, universities, and churches (Embrick 2011; see also Bell and Hartmann 2007; Marti and Emerson 2014). Both individuals and organizations value the idea of racial equality but make little or no systematic changes in their practices to enable it. Thomas (2018) called this "staging difference," whereby organizations strategically make visible people of color to give the impression of diversity and equality, while maintaining a mostly white leadership that controls resources and decision making.

Racial ideologies operate amid complex "inequality regimes" (Acker 2006), whereby the meaning of race in a particular context is influenced by gender and other axis of inequality, such as class, sexuality, and religion (Collins 2004; Crenshaw 1989; Glenn 2009; McDowell 2017; Ong 2005). The "glass ceiling" concept emerged as a critique to diversity ideologies in the late twentieth century. As women entered male-dominated occupations in record numbers and faced few legal or formal barriers in doing so, women continued to face invisible barriers to occupational ascendancy (Cotter et al. 2001). The negative effects of diversity ideologies are particularly acute for women of color, as organizations may pursue racial diversity by recruiting men of color and gender diversity by recruiting white women (Crenshaw 1989; Ong 2005). As we will describe, the case of the IF:Gathering credentials whiteness while blending multiple racial ideologies, including 
color blindness and diversity discourse, with the gender ideology of conservative evangelicalism. Because racism is not monolithic and racial ideologies are not fixed (Collins 2004), we advance this literature by examining the deployment of modern racial ideologies in the particular social context of U.S. white evangelicalism.

\section{Race and Gender in White Evangelicalism}

Sociologists of religion tend to study race and gender as discrete phenomena (Avishai, Jafar, and Rinaldo 2015; for exceptions see Barron and Williams 2017; Prickett 2015; Rao 2015). Yet throughout its history, gender and race have intersected in American Protestantism (Davis 1981; Fitzgerald 2017). In her study of Women of the Ku Klux Klan (WKKK) in the 1920s, Blee (1991) documented how Klanswomen defied stereotypes as they supported women's suffrage. As Blee (1991) wrote, these women's "views of gender roles were neither uniformly reactionary nor progressive" (p. 3). Instead, the WKKK's agenda combined supporting white Protestant women's rights with racism and anti-Semitism. Lessons from such research suggest that an intersectional lens can overcome dichotomous labels that lack nuance, such as feminist versus antifeminist, right wing versus left wing, and racist versus antiracist (Collins 1990).

This study of how white evangelical women blend racial and gender ideologies to talk about their influence is part of a larger body of scholarship on women's leadership within many kinds of organizations (Acker 2006; Cotter et al. 2001). Research on women clergy and the occupational challenges they face tends to leave out conservative Protestants, because this tradition routinely excludes women from formal leadership roles (Chaves and Eagle 2015; Olson, Crawford, and Deckman 2005). In the context of evangelical ministries, research has examined messages encouraging men to act as leaders in racially diverse contexts (e.g., Heath 2003). Most sociological research on evangelical women, however, tends to overlook how race (whiteness) factors into their gender ideology (see Cochran 2005; Gallagher 2003). Instead, this literature focuses on how gender culture operates interpersonally, that is, how women respond to, uphold, or challenge religious messages and prescriptive advice in their daily lives. This scholarship shows that evangelical women can navigate the constraints of 
their religion as they engage in what Ingersoll (2003) called "creative blending," incorporating secular, feminist sensibilities about women's choices with conservative religious beliefs about women's obligations (see also K. Burke 2012, 2016; Cochran 2005; Griffith 1997). Left largely unexamined is how white women may "creatively blend" their racial and gender statuses to exhibit agency within their religious communities.

White evangelicals have made some efforts toward racial inclusion, especially since the civil rights movement (Barron and Williams 2017; Emerson and Smith 2000; Marti and Emerson 2014; Tisby 2019). Previous research shows that for their congregations, efforts at diversity and what they often call "racial reconciliation" reinscribe white norms and authority (Cobb, Perry, and Dougherty 2015; Emerson and Smith 2000; Perry 2012; Tisby 2019), manage and limit the participation of people of color (Barron and Williams 2017; Bracey and Moore 2017; Stanczak 2006), perpetuate antiblack attitudes and micro-aggressions against people of color (Bracey and Moore 2017; Tranby and Hartmann 2008), and limit dialogue about racial politics or systemic racism (Barron and Williams 2017; Edgell Becker 1998; Emerson and Smith 2000; Perry 2017; Tisby 2019). Furthermore, whites in multiracial congregations may have more diverse friendship networks than whites in mostly white congregations (Polson and Dougherty 2018) but tend to have attitudes about racial inequality similar to whites in mostly white congregations, suggesting that multiracial congregations led by whites do not inevitably lead to progressive racial attitudes (Cobb et al. 2015).

Our study updates our understanding of race and racial inclusion in U.S. evangelicalism by examining how evangelical women talk about and express their capacity to lead in a popular Christian women's organization. Drawing from a sociology of race that assumes whiteness operates as an often invisible tool that provides credentials and expanded opportunities (Bonilla-Silva 2015; Feagin 2010; Ray 2019), we examine how white evangelical women combine racial and gender ideologies to disseminate messages about whom and how they can lead. In doing this, we find that these women effectively navigate the gender constraints of their religion for their advantage, while disadvantaging people of color. Our findings show how efforts related to women's leadership and racial diversity may reinscribe both a gender and racial status quo in American evangelism. 


\section{Data and Methods}

Conducting this study of IF conferences was an inductive decision resulting from qualitative research conducted by McDowell, who was a participant-observer at a predominately white Southern Baptist church in northeast Mississippi and was invited to attend a "live viewing" of the 2017 IF:Gathering. McDowell watched that IF conference with about 100 women from other congregations in the region at a midsize church. In 2018, these women held viewing parties in their homes instead of a church. Both settings, local churches and private homes, match how other women view the conference outside of Austin, Texas, where the live event is held (see Figure 1). As scholars of U.S. evangelical culture with an interest in conservative politics, we became interested in the IF:Gathering precisely because it offers a unique opportunity to understand how messages about race and women's leadership are presented to women across the country, in big cities and rural towns, at the same time across the United States. Because IF conferences are publicly available, we did not change the name of the IF:Gathering organization or the names of evangelical celebrities who speak from the IF stage.

We consider talk an important way in which humans construct and organize religious beliefs about who they are and who they ought to be (Wuthnow 2011). To investigate how IF speakers talk about and promote women's leadership, we performed an in-depth qualitative content analysis of each IF:Gathering conference session between 2015 and 2018 (the first conference in 2014 was not available for digital download and therefore not included in the study). In total, we analyzed all 98 sessions from the four available IF:Gathering annual conferences $(2015,2016,2017$, and 2018). The average length of recordings for each conference year was approximately seven hours, with sessions ranging from two minutes of prerecorded IF ministry advertisements to one-hour sessions. There were five types of sessions: (1) featured sermons or "talks" by individuals, usually evangelical female celebrities; (2) group talks about issues such as church involvement or racial reconciliation; (3) religious ceremonies of prayer, confession, or communion; (4) prerecorded videos about local IF groups; and (5) prerecorded video advertisements for nonprofit and for-profit companies and organizations. The aim of our content analysis of the sessions was to "document and understand the communication of 
meaning" by transcribing what was said and how it was said and then placing statements about women's ministries and leadership within their proper context (Altheide 1987:68; Altheide and Schneider 2013).

Our first step in data analysis was to code each conference session on the basis of a number of explanatory criteria, including the type of session (feature speaker, live group discussion, or prerecorded video), its apparent racial makeup (white only, women of color only, or multiracial), and keywords to describe the content or focus of the session (e.g., global ministry promotion, sermon about obedience). Next, we began in-depth content analysis of every conference session to allow new categories and concepts to emerge. Unlike quantitative content analysis, which measures the frequency and variation of messages, the analytic approach we use is systematic "but not rigid" in data coding and concept development (Altheide 1987:68). To ensure cross-coder reliability, the research team (both authors and a research assistant) started by watching and coding all sessions from the 2016 conference. For this step, we used a spreadsheet to create open codes and to transcribe select data along with their timestamp. Our 2016 spreadsheet contained 443 rows of coded data. Each row included both verbatim quotations and a description of context for these quotes (e.g., the topic, scripture, or life event that was the focus of the session or speakers). On this spreadsheet, we also describe how and when speakers made gestures with their hands, moved around on stage, and shifted their tone of voice.

After our initial round of extensive transcription and coding, we noted "leadership" as a prominent theme and created a list of deductive codes that capture how IF talks about leadership in explicit and implicit ways at the conference. These provisional codes were the basis for axial coding, which tested the relationships between emergent categories related to leadership and how they connected to broad themes of women's ministry. The most prominent axial codes created from our initial leadership code were "God in charge," "small acts," "solutions to social problems," "racial Others," and "global mission." To test the relationship between these emergent codes, the research team rewatched the 2016 sessions along with all conference sessions in 2015, 2017, and 2018. This allowed initial categories to be confirmed or rejected on the basis of whether the same codes continued to emerge from the data (Corbin and Strauss 2008). Subsequent analyses of the relationships between our axial codes revealed how 
IF women's leadership maintains racial and gender hierarchies within evangelical ministries.

We determined a saturation point when rewatching conference sessions revealed no new codes or themes. One limitation of our ethnographic content analysis of these videos (and possible avenue of future research) is that we cannot assess how these messages are interpreted by IF participants or reflected upon by IF speakers. Many of the women who lead from the IF stage are evangelical celebrities who remain active in the public sphere. The data we present are snapshots in time and do not capture women who may have changed their positions on various political issues since appearing at IF. This study instead analyzes the messages of this large women's ministry to understand how race and gender intersect as women express leadership in a conservative religious context.

\section{White Women Are Equipped to Lead}

At the IF:Gathering, featured speakers repeat the point that Christian women are capable of and called to influence others. Their messages reflect the official motto of IF-"gather, equip, and unleash" - gather women together through the annual conference and more frequent IF:Local meet-ups, equip women for discipleship, and unleash Christian women to solve social problems and implement positive social change. Although they only occasionally use the terms leader and leadership, IF speakers consistently encourage women to act as leaders within their communities. In 2015, Lynne Hybels, a white author, pastor's wife, and missionary, said emphatically, "I've become convinced that women are the greatest untapped resource in the world." In 2017, Rebekah Lyons, another white author and regular IF speaker, urged the audience to push past self-doubt and heed God's calling: "Stop waiting for someone more trained and more eloquent and more astute to speak-You speak."

The subsequent sections show how IF women's messages surrounding Christian women's leadership are racialized and reproduce a racial and gender order that does not threaten the authority of white Christian men. The first section, "God Equips White Women to Lead," examines how IF women insist that they are leaders when they refuse to take credit for their accomplishments and express obedience to God. 
We argue that this color-blind message about leadership maintains the racial and gender order of evangelicalism while allowing women to describe leadership, or influencing others, through "small acts" of discipleship, such as having a stranger over for dinner or organizing a Bible study in their homes. The second section, "Diverse Friendships Equip White Women's Leadership," examines how these "small acts" are distinctly feminized and racialized as mostly white women describe cultivating deliberately diverse friendships with women of color as an act of Christian goodwill. Speakers intentionally present IF:Gathering as a diverse enterprise but consistently prioritize the voices and perspectives of white women over women of color. The final section, "Diversity Projects Equip White Women's Leadership," shows how white evangelical women position themselves as leaders as they minister to women and children of color living in dire circumstances and often faraway places. Together, these findings reveal that the mostly white leaders of IF mobilize particular racial and gender ideologies to talk about women's leadership within the constraints of their conservative religion (i.e., white women cannot lead white men). The result makes room for a model of women's leadership within evangelical Christianity that is palatable and nonthreatening to the status quo.

\section{God Equips White Women to Lead}

IF promotes the idea that women are fully equipped, even ideally suited, for certain forms of leadership, especially the act of leading others to Christ. According to IF speakers, when women "walk with Jesus," they embody feminized qualities of leadership that are undervalued in most gendered organizations: being loving, communal, and compassionate. Through submission to God and an emphasis on "small acts" of ministry, women move past their "weaknesses" and see themselves as God sees them: fully capable and equipped to lead in evangelical Christianity. On the surface, these messages about leadership appear race neutral, speaking to all Christian women regardless of race. Yet they align with what Feagin (2010) called a "white racial frame," whereby the mostly white speakers at IF treat their experiences as normal and universal.

Each year, Jennie Allen, a white woman and the self-described leader of IF:Gathering, is among the first speakers of the conference. Although the content of her talk differs from year to year, she returns 
to common themes, including how God sent her the message to "disciple a generation" and how she was wildly unprepared for this task. In 2015, Jennie shared a story about when she prayed to God that "I can't do this. ... But you know what ... I've embraced the fact that I can't do this, because you know what: God can." Jennie downplayed her role as a leader again in 2018. From the stage, she admitted that she worries that when the IF:Gathering ends, she and others will lose the will to be God's disciples. Then she explained why this is a silly concern: "The story of God is marching on, despite our sin, despite our inadequacy, and despite our weakness." Women lead when they are obedient to God, she implied, and therefore do not have anything to worry about. They are not really in charge.

It is precisely by placing the emphasis on God that the mostly white speakers at IF gloss over white dominance in most conference sessions. Women featured at IF:Gatherings give the impression that were it not for God's choosing them to lead, they would be ill prepared and therefore would not be on the stage. Hence, when acknowledging their roles as leaders (even if those leadership roles are fleeting), the white speakers at IF commonly downplay their capacity to lead and instead express obedience to God. During a group confession session in 2016, one white participant claimed, "I'm so humbled and a little nervous to lead us through such a sacred expression ... of letting ourselves come fully before God, dirt and all, and letting Him do what only He can do." To overcome her nervousness as a leader, this participant put the emphasis on God rather than her own abilities. Ellen Tucker, another white woman, also did this when she appeared in the 2017 IF:Gathering Group Talk. Ellen described herself as an ordinary mom, physical education teacher, and coach and told the audience that she did not understand why she was invited onto the IF stage. Ellen is a self-described "nobody" who has "nothing to say." Then, Ellen turned her self-deprecation into a spiritual gift, noting that her seemingly insignificant roles as a mentor and mom are just as important as "going to Africa" on a mission trip. Besides, she reassured the audience, "I don't do anything. God does all of it." This language gives the impression that all Christian women can follow God's lead but masks the fact that it is mostly white women who are afforded leadership roles on the IF stage.

IF leaders acknowledge that white women may feel unfit to lead because of the conflicting messages they receive about what it means 
to be a woman in U.S. society. In 2016, Shelley Giglio, a white woman, affirmed,

I think it's confusing sometimes for women because we're told we can do certain things or we're told we don't do certain things, or we should be certain ways or we shouldn't be certain ways or there's certain expectations over our lives.

The blending of positive and negative expectations that Shelley referenced is reflective of her experience as a white woman and is largely unavailable to women of color in the United States who face persistent and harsher negative stereotypes (Collins 2004). Jo Saxton, a black woman from the United Kingdom, also universalized women's experiences as she observed in 2018 how women draw "these crazy comparisons" with one another: "My child slept through the night at four weeks." Jo then mimicked more responses to rising laughter: "My child slept through the night at two weeks. My child was born sleeping through the night." These comparisons among women, according to Jo, are because women are afraid that they are never enough. This example of "mommy insecurities," along with the other examples she invokes - "popularity contests" and "winning the guy"-are reflective of white, middle-class ideologies that privilege a traditional heterosexual family. After describing women's self-doubt, fears, and misguided motivations, Jo shifted her focus to the power of God: "The God who loves you and is always seeing you also empowers you!"

A 2015 conversation between mother and daughter Lynne Hybels and Shauna Niequist (both white authors) is an illustrative example of how whiteness goes unmarked in messages intended to empower women but that also minimize their efforts. Lynne, author of the book Nice Girls Don't Change the World (Hybels 2005), explained that she wrote the book so that girls could learn a different gender perspective than the one she was raised to believe. Here she universalized the experience of girls who are expected to be "nice," a label that is not afforded to black girls in the United States (Cooper 2018). Lynne grew up believing that a woman's job was primarily to support her husband, but she now believes that women should be empowered by their own convictions and efforts. Her adult daughter, Shauna, described the change in Lynne, who went from being a homemaker to a 
global missionary and who helps "some of the most endangered and forgotten people" in the world. Lynne acknowledged her efforts to help an orphanage in Mexico, but then asserted, "I never had a great plan. I've never been on the paid staff at [my home church]. I'm still a volunteer. But I've had the privilege of taking one step after the next into issues that I care about." Although she described her work as important, Lynne also dismissed her work "as a volunteer," suggesting that her achievements are God's rather than her own. By emphasizing God's influence in her life, she also minimized the racial and class privilege that enable her "volunteer" leadership, which requires international travel and unpaid time.

\section{Diverse Friendships Equip White Women's Leadership}

The small act of friendship is one of the primary ways IF speakers describe the leadership of Christian women. Leadership as friendship is the theme in IF's Montage videos, a series of short prerecorded videos that profile individual women talking about their Christ-centered friendships with other women. In the 2017 Montage series, several young women take turns explaining how simple expressions of friendship can have big consequences. Jaci, a white woman, tells the camera about her friend Julie, who made her "believe." Julie did the small act of inviting Jaci for a run, an invitation that turned into a four-year relationship of running and training for marathons. Through this friendship, Jaci learned that "a simple weekly invitation, listening, prayer, and setting running goals together is a unique opportunity for discipleship." Now Jaci invites other women on runs, leading them to Christ through a weekly, friendly commitment. Other members of the Montage cast make the same claim about the power of Christian friendship. Cathy says that her friend Denise pulled her out of a crisis when she reached out and invited her to a Bible study, and Jinny credits her Christian friend Leanne for showing her that "sometimes communion looks more like grilled cheese and tomato soup than crackers and juice." "Because of her," she continues, "I have the courage to open my doors, and my arms, and my ears and my heart to welcome people in the name of Christ."

The IF:Table is a prominent example of how racial ideologies are embedded within the gendered notion of leadership through friendship. At the IF:Gathering conference and on its Web site, the audience 
learns that they can sign up to be IF:Table hosts. For women who sign up to be table hosts, IF e-mails four questions (and occasionally recipes) each month to prompt a two-hour discussion among small groups of women. Susie Davis, a white woman who created the IF:Table ministry, told participants at the $2016 \mathrm{IF}$ conference that small acts of ministry have big impacts:

I just want to invite you to consider the possibility that your life could be radically changed, your neighborhood, your hometown, things could really happen by doing something really simple. Just being brave enough to invite people into your life and just look across the table and say, "I see you and I want to hear your story."

From this perspective, leadership is the "brave" act of listening to others and befriending strangers over a shared meal.

The local IF:Tables featured at the IF:Gatherings typically present the most meaningful (and most difficult) friendships as racially and ethnically diverse. They are one example of the importance that IF places on "racial reconciliation," a phrase some evangelicals use to indicate a desire to cultivate relationships across racial groups to eliminate racial discrimination and prejudice in the church (Oyakawa 2019; Tisby 2019). We find that "racial reconciliation" and other "diversity projects," which are common of many white dominated organizations, including evangelical groups (Barron and Williams 2017; Marti and Emerson 2014; Thomas 2018), are opportunities to define women's leadership in racialized terms. Specifically, white speakers commonly talk about themselves as leaders as they describe their Christian influence on racialized others and what some evangelicals call "racial healing."

Renee Law, a white woman and IF:Table leader featured in a 2017 conference prerecorded video, uses a racially diverse table to describe the ministry she leads in her hometown in Huntington, West Virginia. At this table, Renee gathers women "from the community" (who, we see in the video, are black women) to meet and share a meal together once a week. She claims, "These ladies are my best friends." As white and black women dine together in the background, Renee narrates that at her Table, "Nobody is viewed as a project. Nobody is viewed as less than anybody else. Nobody is viewed as a better than anybody else.... We're all the same- and we're all equal when we're 
around the table." Renee's implicit message about how her Table ministry levels the playing field between black and white women assumes that white women are or will be in charge of the Table and that white women typically view poor women and women of color as a "project" or a problem to be solved. Her message also resonates with what white speaker Jen Hatmaker said about the power of "loving connections" at IF in 2016. After noting, "When we love people as friends, we love them as equals," Hatmaker implied that interracial friendships force evangelical women to confront "inequitable systems" within society. She did not draw attention to racial privilege and instead suggested that racial injustices can be solved when white women are kind to women of color. Over the years, Hatmaker has become more explicit in her critique of white privilege, as well as conservative politics, and tellingly has not reappeared on the IF stage since 2016.

As these examples illustrate, "happy talk" about diversity (Bell and Hartmann 2007) permeates the IF conference. It is talk that celebrates racial and cultural difference in the church while also undermining serious talk about the racial inequalities associated with those differences (Marti and Emerson 2014; Thomas 2018). Indeed, the optics of the conference stage present an image of racial diversity and multiculturalism, which masks how white women continue to dominate the conference. Despite efforts of racial diversity, the structure and focus of the IF conference limits who is highlighted as a leader. Figure $\mathbf{2}$ shows that there is discrepancy in the number of women of color who appear on stage as part of larger groups and women of color who

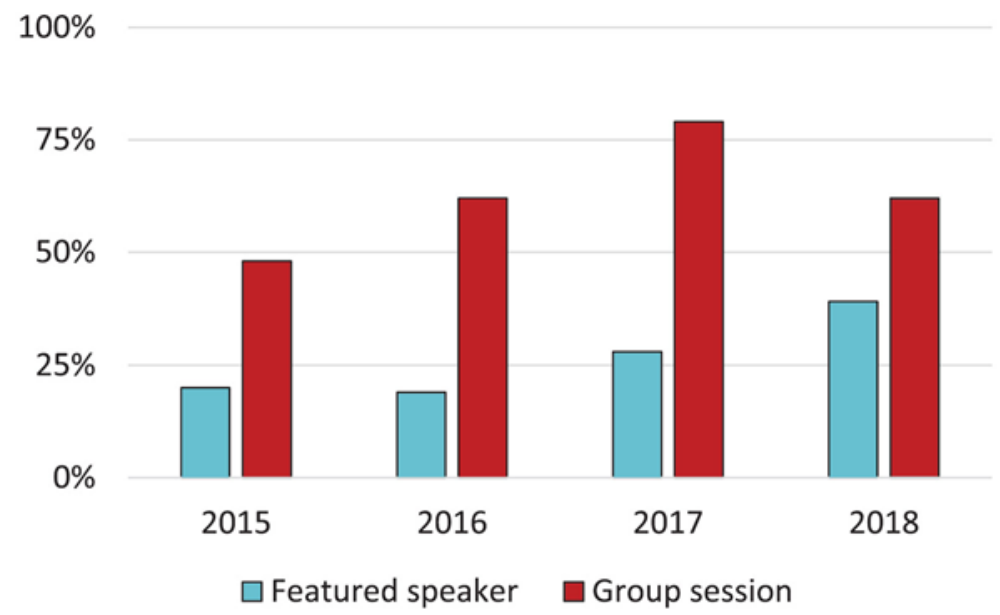

Figure 2. Representation of women of color by conference session type. 
appear on stage by themselves as featured speakers in each year of the conference we analyzed. Between 48 percent (2015) and 79 percent (2017) of group conference sessions featured women of color. Yet white women made up the vast majority of feature speaker sessions (those in which a single woman took the stage or was featured in a prerecorded video). Women of color constituted 19 percent (2016) to 39 percent (2018) of featured speakers at the IF:Gathering. These data show that IF cultivates an illusion of racial diversity while amplifying the voices of white women.

Sessions on racial reconciliation are among the few gatherings at which women of color have the opportunity to present their own messages about women's friendships and leadership. Between 2015 and 2017, IF partnered with Be the Bridge (BTB) ministries, a racial reconciliation program and social media platform spearheaded by LaTasha Morrison, an African American woman, who also leads the BTB sessions at IF. These conversations typically focus on how racially diverse friends can strengthen one another's relationship with Jesus. In 2015, Jaime Ivey, one of the white women sitting at the table, answered a question about why it is important for her to have friends of a different race: "It makes me a better person, a better mom, a better Christ follower." Helen Lee, a Korean American woman, spoke about how a white friend provided her with personal and spiritual healing when she took an interest in Korean food (which she referred to as "stinky pickled cabbage stuff"). Helen explained, "For many years, I had been stereotyped and marginalized, and to have a friend from a dominantmajority group say 'your culture means something to me!' was unbelievably healing." Helen's remarks about the joy she derived from acceptance by her white peers is one of many examples in which women engage in "happy talk" about diversity on the IF stage.

In 2017, a month after Donald Trump was sworn in as president, the African American leaders of IF's BTB session moved away from the usual happy talk and set a different tone for the discussion about racial reconciliation in friendship. Rather than idealizing nurturing friendships between black and white women, as was typical in 2015 and 2016, the black women at the table pressed white women to contemplate why interracial friendships are emotionally taxing for women of color. At the beginning of this session, LaTasha Morrison squinted her eyes and leaned forward, as if she is letting the mostly white audience in on a little secret: 
Let me just be really honest-We're tired. We're weary. Sometimes you don't want to be in a space where you know you're going to be wounded. ... Not intentionally, but we know that sometimes people are oblivious. That takes a lot.

Following this, LaTasha turned to Amena Brown, another black woman sitting at the table, and invited her to talk about how women of color are "marginalized." Amena responded that being a woman of color is a "blessing and a burden" and then elaborates on the burden, telling the audience that she is tired of being "shushed or silenced" when she expresses that burden. Amena is "justifiably angry," and she is wary of people in "faith-based contexts" who advise her "to rush to forgiveness without addressing the offense that was done in the first place." She, like LaTasha, charged white evangelical women with being dismissive and "oblivious." The 2017 BTB panelists offered a critique of the typical messages at IF about the positive power of friendship, but this critique was the only one we observed in our analysis. Notably, the 2018 conference did not include a BTB session.

\section{Diversity Projects Equip White Women's Leadership}

The IF conference consistently highlights white voices that use racial diversity to illustrate white women's leadership potential. This racial dynamic is apparent in IF's recurrent videos about global ministries in Africa, South Asia, and Latin America. Each year IF presents a series of prerecorded "story" videos-"Andrea's Story," "Dacia's Story," and so on-at the conference. These five-minute, sleekly produced videos appear between live panel and speaker sessions, and each profiles a woman (who almost always appears white) who is evangelizing to women and children (almost always people of color) who are sex workers, suffer extreme poverty, and/or are living in the global South. A video produced for the 2017 conference introduces Dacia Hamby, a young white woman, originally from Lovett, Texas, who has called Jinha, Uganda, "home for the last five years" as a missionary alongside her husband. She explains how the IF:Equip Bible study helps with her ministry effort. "I can lead an IF:Equip Bible study with a Ugandan and teach her how to translate that and she can lead her own Bible studies in her own village." The video shows Ugandan women 
sitting outdoors beneath a warm glowing sun and listening to Dacia, who is shown talking at the head of the circle. At the close of the IF study, women hug Dacia, assumingly expressing thanks to her one by one. The IF conferences' emphasis on helping women whom speakers describe as living in the "third world" in Africa, South Asia, and Latin America highlights their position on evangelical women's leadership: white women can and should take the lead in ministering to poor women of color.

Although a frequent theme in conference sessions is the lifechanging experience of participating in a global mission to impoverished parts of the world, IF also offers opportunities for women to shape the lives of the global downtrodden without ever leaving the comforts of their home. Each year, IF shows short promotional videos featuring opportunities to buy jewelry, make donations, or sign a petition for a good cause. Every year women from the leadership team of the evangelical nonprofit organization, International Justice Mission (IJM) make an appearance at IF. During these guest appearances, IJM leaders stress their spiritual commitment to ending slavery around the world, pointing out that God calls them to "rescue others." In 2016, IJM asked the audience to do one small thing that could make a big difference: sign their petition. In 2017, IJM followed up on this request, telling the IF participants that "over 3,000 women from around the globe signed up to be freedom partners. Because of you, IJM rescued over 4,000 individuals." Their message of rescue was reinforced by an image of an Indian woman with long hair, a nose ring, and a bright white sari displayed on a screen behind the IJM staff. After this, the IF audience of mostly white women is shown raising their hands in praise.

IF leaders also emphasize how their Christian efforts can empower "third world" women to help themselves out of destitute poverty, a message that champions a "bootstrapping" mentality while also undermining social support systems such as global aid. Noonday, a business that carries jewelry from "artisans across the globe," is commonly featured at the IF:Gatherings. In a 2017 video, this jewelry, the audience is told, can be sold through "home shows," much like Tupperware or Mary Kay cosmetics. Its founder, a white woman from the United States, Jessica Honegger, interviews Jennie Allen about why she hosts Noonday shows in her home every year. Jennie smiles, "I love it. I love getting jewelry. I love having friends over. I always make a big cheese 
board. It's easy." Noonday is something Jennie "believes in" because she was "on the ground" in Rwanda. There Jennie witnessed

women that were in the trenches building the jewelry that didn't have jobs, they were living in poverty. And now they're empowered. They're sending their own kids to school. They have homes for their parents-they have become leaders in their community.

Coupled with this message that IF women empower Other women to become leaders, the images on the screen shift between white women chatting and trying on jewelry in Jennie's sleek upper-middle-class home and Rwandan women beading thread, discussing designs, and clapping and singing praise to God. Following these images, Jennie grins and says, "I just believe that if I can get a dozen friends together and that gives somebody a job, then that is a good use of the night. And we have fun!" According to Jennie, the small act of hosting a jewelry party for friends can solve significant social problems like unemployment, poverty, and hunger around the globe.

IF speakers insist that their ministries "in the trenches" also happen by helping their dispossessed neighbors in urban contexts. IF:Gathering 2015 asked participants for donations for the nonprofit organization Feed the Children. On stage, Jennie talked to Tracy McConduit, an African American woman who was once a recipient of Feed the Children's services and is now a "disciple" who directs its "Center for a New Generation" program, in which she works closely with public schools in Dallas. "You're who Feed the Children helps," Jennie said directly to Tracy. She, the audience then learned, lived in New Orleans and "lost everything" when Hurricane Katrina hit. Tracy shared her story and how she had to learn to receive "help" from others. Jennie shared that she used to live in "a little two-story blue house right across the highway" from one of the schools that Tracy's program supports but that she "didn't know" about the poverty and hunger so close to her home. As Jennie asked the audience for donations, she asserted that they have a domino effect: "This is women helping women helping women helping women."

IF identifies helping diverse marginalized women as an explicit goal of Christianity but only so far as to enhance the spiritual and human relationships of mostly white Christian women, rather than to reduce 
inequality across social groups or to radically transform the structure of evangelicalism (see also Perry 2017). Indeed, the limitations of their social justice mission is evident when they talk about rescuing women and children "in the trenches." Significantly, these groups refer to those who are economically, racially, and sexually oppressed (i.e., mothers without husbands, children without homes, families who are hungry, and women who do sex work). It is here that IF women make their claim to leadership in evangelical Christianity most apparent, pointing out that women, not men, are equipped to lead others who suffer these conditions. This finding is significant for sociologists of race, religion, and gender. It illustrates that although conservative religious women may be optimizing their choices amid gender hierarchies, they may also be limiting the ability of women of color to make those same choices, much less attain formal positions of power (see also Bowler 2019).

\section{Conclusion}

Our study shows how white women effectively use a combination of racial and gender ideologies to define and promote women's leadership on a national evangelical stage. We offer three primary contributions to the sociology of race and ethnicity. First, the model of women's leadership presented at the IF:Gathering offers a greater understanding of how whiteness operates as a credential within womenled religious organizations. The white speakers of IF are most effectively able to tailor their religious messages to respond and adapt to changing gender norms, particularly with regard to women's capacity for leadership. The findings show that even though these women insist that all women, regardless of race, can be leaders because God is leading, mostly white women appear on the IF stage. This, we argue, reinforces a pervasive yet unacknowledged assumption within evangelical circles that whites, particularly middle- and upper-middle-class whites, lead because God chose them to lead, not because of structural inequalities that privilege whites. Furthermore, IF speakers rhetorically place importance on the "small" things women do and imply that those acts can have the greatest influence. These messages about leadership suggests that women are teachers, not preachers, of the faith and that if women would just be kind to one another, 
their differences can and should melt away. When white IF speakers equate women's leadership with "small acts" of Christian goodwill, they may dissuade both white women and women of color from trying to achieve formal positions of power in a religious tradition that privileges white men and men's authority.

Second, our intersectional analysis of IF situates religion within its proper context, helping explain both the complex and multifaceted identities of religious women and how religion influences and is influenced by intersecting racial and gender inequalities (Collins 1990). Others have noted how white evangelicals committed to social justice may avoid acknowledging the structural or systemic causes of injustice (Barron and Williams 2017; Edgell Becker 1998; Emerson and Smith 2000; Perry 2017), but this body of research tends to focus exclusively on race (whiteness) rather than on how race and gender intersect. We find that in the case of the IF:Gathering, white IF speakers were able to most effectively validate and lay claim to their leadership as women. IF women do this as they describe their influence on other white women and people of color. Furthermore, though the IF:Gathering explicitly celebrates multiracial friendships and makes time for conversations about "racial reconciliation," this conference does not wrestle with the structure of white supremacy and racial injustice. Instead, the voices of white women who are shown caring for and helping women in dire circumstances are highlighted in the name of diversity. On the rare occasions when race and racism were mentioned, women of color were charged with taking the lead. Yet even in these moments, whiteness permeates what is and is not said as evidenced by the many conference sessions that highlight white women and women of color engaging in "happy talk" (Bell and Hartmann 2007).

Finally, the case of the IF:Gathering sheds light on the relationship between race, gender, and religion in U.S. politics. Although there is a large body of scholarship on the emergence of a "new" racism following the civil rights movement in the United States, the broad spectrum of racial ideologies - from "all lives matter" to the so-called altright-in the Trump era are deserving of new empirical examination (Burke 2017). Exit polls from the 2016 presidential election found that among religious Americans, the only group whose majority voted for Trump was white Christians (more than 80 percent of white evangelical voters) (Smith and Martínez 2016). Furthermore, most white evangelical women voted for Trump compared with female voters in general, 
who were more likely to vote for Clinton (Paquette 2016; Shellnutt 2017). Our findings offer a qualitative account of this strong relationship between white evangelical women and conservative politics that has been observed in polling data. Although IF speakers avoid explicit talk of politics, the messages presented at IF:Gathering reveal how white evangelical women may prioritize white Christian leadership because they believe the nation must grow closer to Christ in order to solve momentous social and global inequalities. This model of leadership supports what some scholars call Christian nationalism (Gorski 2017; Whitehead, Perry, and Baker 2018). In fact, the IF version of women's leadership is particularly well suited to advance contemporary evangelicalism amidst competing yet complementary color-blind and diversity ideologies. White women's performance of love, compassion, and friendship counters the image of evangelicals as evil colonizers, theocrats, or nationalists. But our study of the IF conference shows that it does not challenge or significantly alter old agendas of the Religious Right. Future research on women's leadership in evangelicalism could explore this further by examining (1) how ordinary women interpret and act on these messages of leadership in their local churches and (2) if and how the language of women's leadership pushes women from diverse racial backgrounds to critically reflect on gender and racial hierarchies in the evangelical church.

Acknowledgments - This research was partially supported by the University of $\mathrm{Ne}$ braska-Lincoln Department of Sociology Haas Faculty Research Award and the University of Nebraska- Lincoln Undergraduate Creative Activities and Research Experience program. We thank Eliza Thor for her research assistance and Kirsten Dellinger, Melanie Heath, and Rachel Rinaldo for their support and feedback on this article.

\section{References}

Acker, Joan. 2006. "Inequality Regimes: Gender, Class, and Race in Organizations." Gender \& Society 20(4):441-64.

Altheide, David L. 1987. "Reflections: Ethnographic Content Analysis." Qualitative Sociology 10(1):65-77.

Altheide, David L., and Christopher J. Schneider. 2013. Qualitative Media Analysis. 2nd ed. Thousand Oaks, CA: Sage.

Avishai, Orit, Afshan Jafar, and Rachel Rinaldo. 2015. "A Gender Lens on Religion." Gender \& Society 29(1):5-25. 
Barron, Jessica M., and Rhys H. Williams. 2017. The Urban Church Imagined: Religion, Race, and Authenticity in the City. New York: New York University Press.

Beaty, Katelyn. 2017. "Why Evangelical Women Leaders Don't Talk about Politics." Religion and Politics. http://religionandpolitics.org/2017/12/19/ why-evangelical-women-leaders-dont-talk-about-politics/

Bell, Joyce M., and Douglas Hartmann. 2007. "Diversity in Everyday Discourse: The Cultural Ambiguities and Consequences of 'Happy Talk."' American Sociological Review 72(6):895-914.

Blee, Kathleen M. 1991. Women of the Klan: Racism and Gender in the 1920s. Berkeley: University of California Press.

Bobo, Lawrence, James R. Kluegel, and Ryan A. Smith. 1997. "Laissez-Faire Racism: The Crystallization of a Kinder, Gentler, Antiblack Ideology." Pp. 23-25 in Racial Attitudes in the 1990s: Continuity and Change, edited by S. A. Tuch and J. K. Martin. Westport, CT: Praeger.

Bonilla-Silva, Eduardo. 2015. Racism without Racists: Color-Blind Racism and the Persistence of Racial Inequality in the United States. 4th ed. Lanham, MD: Rowman \& Littlefield.

Bonilla-Silva, Eduardo. 2016. "More Than Prejudice: Restatement, Reflections, and New Directions in Critical Race Theory." Sociology of Race and Ethnicity 1(1):73-87.

Bowler, Kate. 2019. The Preacher's Wife: The Precarious Power of Evangelical Women Celebrities. Princeton, NJ: Princeton University Press.

Bracey, Glenn E., and Wendy Leo Moore. 2017. "'Race Tests': Racial Boundary Maintenance in White Evangelical Churches." Sociological Inquiry 87(2):282-302.

Burke, Kelsy. 2012. "Women's Agency in Gender-Traditional Religions: A Review of Four Approaches." Sociology Compass 6(2):122-33.

Burke, Kelsy. 2016. Christians under Covers: Evangelicals and Sexual Pleasure on the Internet. Berkeley: University of California Press.

Burke, Kelsy, and Amy McDowell. 2012. "Superstars and Misfits: Two Pop-Trends in the Gender Culture of Contemporary Evangelicalism." Journal of Religion and Popular Culture 24(1):67-79.

Burke, Kelsy, Dawne Moon, and Theresa Tobin. Forthcoming. "Shame and Entitlement: Race and the Religious Possibilities for Sexuality in Conservative Christianity." In Religion Is Raced: Understanding American Religion in the 21st Century, edited by G. B. Yukich and P. Edgell. New York: New York University Press.

Burke, Meghan. 2012. Racial Ambivalence in Diverse Communities: Whiteness and the Power of Color- Blind Ideologies. Lanham, MD: Lexington Books.

Burke, Meghan. 2017. "Colorblind Racism: Identities, Ideologies, and Shifting Subjectivities." Sociological Perspectives 60(5):857-65.

Chaves, Mark, and Alison Eagle. 2015. "Religious Congregations in 21st Century America." Durham, NC: The National Congregations Study. http://www.soc. duke.edu/natcong/Docs/NCSIII report final.pdf 
Cobb, Ryon J., Samuel L. Perry, and Kevin D. Dougherty. 2015. "United by Faith? Race/Ethnicity, Congregational Diversity, and Explanations of Racial Inequality." Sociology of Religion 76(2):177-98.

Cochran, Pamela C. H. 2005. Evangelical Feminism: A History. New York: New York University Press.

Collins, Patricia Hill. 1990. Black Feminist Thought: Knowledge Consciousness, and the Politics of Empowerment. New York: Routledge.

Collins, Patricia Hill. 2004. Black Sexual Politics: African Americans, Gender, and the New Racism. New York: Routledge.

Cooper, Brittney. 2018. Eloquent Rage: A Black Feminist Discovers Her Superpower. New York: St. Martin's.

Corbin, Juliet, and Anselm Strauss. 2008. Basics of Qualitative Research: Techniques and Procedures for Developing Grounded Theory. 3rd ed. Thousand Oaks, CA: Sage.

Cotter, David A., Joan M. Hermsen, Seth Ovadia, and Reeve Vanneman. 2001. "The Glass Ceiling Effect." Social Forces 80(2):655-81.

Crenshaw, Kimberle. 1989. "Demarginalizing the Intersection of Race and Sex: A Black Feminist Critique of Antidiscrimination Doctrine, Feminist Theory and Antiracist Politics." University of Chicago Legal Forum 1989:139-67.

Davis, Angela Y. 1981. Women, Race, and Class. New York: Vintage.

Edgell Becker, Penny. 1998. "Making Inclusive Communities: Congregations and the 'Problem' of Race." Social Problems 45(2):451-72.

Embrick, David G. 2011. "The Diversity Ideology in the Business World: A New Oppression for a New Age." Critical Sociology 37(5):541-56.

Emerson, Michael O., and Christian Smith. 2000. Divided by Faith: Evangelical Religion and the Problem of Race in America. New York: Oxford University Press.

Feagin, Joe. 2010. The White Racial Frame: Centuries of Racial Framing and Counter-Framing. New York: Routledge.

Fitzgerald, Frances. 2017. The Evangelicals: The Struggle to Shape America. New York: Simon \& Schuster.

Gallagher, Sally K. 2003. Evangelical Identity and Gendered Family Life. New Brunswick, NJ: Rutgers University Press.

Glenn, Evelyn Nakano. 2009. Unequal Freedom: How Race and Gender Shaped American Citizenship and Labor. Cambridge, MA: Harvard University Press.

Golash-Boza, Tanya. 2016. "A Critical and Comprehensive Sociological Theory of Race and Racism." Sociology of Race and Ethnicity 2(2):129-41.

Gorski, Philip. 2017. "Why Evangelicals Voted for Trump: A Critical Cultural Sociology." American Journal of Cultural Sociology 5(3):338-54.

Griffith, R. Marie. 1997. God's Daughters: Evangelical Women and the Power of Submission. Berkeley: University of California Press.

Heath, Melanie. 2003. "Soft-Boiled Masculinity: Renegotiating Gender and Racial Ideologies in the Promise Keepers Movement." Gender \& Society 17(3):423-44. 
Higginbotham, Evelyn Brooks. 1993. Righteous Discontent: The Women's Movement in the Black Baptist Church, 1880-1920. Cambridge, MA: Harvard University Press.

Hybels, Lynne. 2005. Nice Girls Don't Change the World. Grand Rapids, Ml: Zondervan.

Ingersoll, Julie. 2003. Evangelical Christian Women: War Stories in the Gender Battles. New York: New York University Press.

Manning, Alex, Douglas Hartmann, and Joseph Gerteis. 2015. "Colorblindness in Black and White: An Analysis of Core Tenets, Configurations, and Complexities." Sociology of Race and Ethnicity 1(4):532-46.

Marti, Gerardo, and Michael O. Emerson. 2014. "The Rise of the Diversity Expert: How American Evangelicals Simultaneously Accentuate and Ignore Race." Pp. 179-99 in The New Evangelical Social Engagement, edited by B. Steensland and P. Goff. New York: Oxford University Press.

McDowell, Amy D. 2017. "'This Is for the Brown Kids!': Racialization and the Formation of Muslim Punk Rock." Sociology of Race and Ethnicity 3(2):159-71.

Nilsen, Sarah, and Sarah E. Turner, eds. 2014. The Colorblind Screen: Television in Post-racial America. New York: New York University Press.

Olson, Laura R., Sue E. S. Crawford, and Melissa M. Deckman. 2005. Women with a Mission: Religion, Gender, and the Politics of Women Clergy. Tuscaloosa: University of Alabama Press.

Ong, Maria. 2005. "Body Projects of Young Women of Color in Physics: Intersections of Gender, Race, and Science." Social Problems 5(4):593-617.

Oyakawa, Michelle. 2019. "Racial Reconciliation as a Suppressive Frame in Evangelical Multiracial Churches." Sociology of Religion 80(4):496-517.

Paquette, Danielle. 2016. "The Unexpected Voters behind the Widest Gender Gap in Recorded Election History." The Washington Post. https://www.washingtonpost.com/news/wonk/wp/2016/11/09/ men-handed-trump-the-election/?utm term $=.7574 \mathrm{cb} 6 \mathrm{e} 1702$

Perry, Samuel L. 2012. "Racial Habitus, Moral Conflict, and White Moral Hegemony Within Interracial Evangelical Organizations." Qualitative Sociology 35(1):89-108.

Perry, Samuel L. 2017. Growing God's Family: The Global Orphan Care Movement and the Limits of Evangelical Activism. New York: New York University Press.

Polson, Edward C., and Kevin D. Dougherty. 2018. "Worshipping across the Color Line: The Influence of Congregational Composition on Whites' Friendship Networks and Racial Attitudes." Sociology of Race and Ethnicity 5(1):100-14.

Prickett, Pamela J. 2015. "Negotiating Gendered Religious Space: The Particularities of Patriarchy in an African American Mosque." Gender \& Society 29(1):51-72.

Putnam, Robert D., and David E. Campbell. 2010. American Grace: How Religion Divides and Unites Us. New York: Simon \& Schuster.

Rao, Aliya Hamid. "Gender and Cultivating the Moral Self in Islam: Muslim Converts in an American Mosque." Sociology of Religion 76(4):413-35. 
Ray, Victor. 2019. "A Theory of Racialized Organizations." American Sociological Review 84(1):26-53.

Shellnutt, Kate. 2017. "Young, Female, and Pro Trump: How White Evangelical Millennials Are Defying Political Predictions." Christianity Today. http:// www. christianitytoday.com/women/2017/july/young-female-and-pro-trump.html

Smith, Gregory A., and Jessica Martínez. 2016. "How the Faithful Voted: A Preliminary 2016 Analysis." Washington, DC: Pew Research Center. http://www.pewresearch.org/fact-tank/2016/11/09/ how-the-faithful-voted-a-preliminary-2016-analysis/

Stanczak, Gregory C. 2006. "Strategic Ethnicity: The Construction of Multi-racial/ Multi-ethnic Religious Community." Ethnic and Racial Studies 29(2):856-81.

Thomas, James M. 2018. "Diversity Regimes and Racial Inequality: A Case Study of Diversity University." Social Currents 5(2):140-56.

Thompson, Jennifer A. 2013. "'He Wouldn't Know Anything': Rethinking Women's Religious Leadership." Journal of the American Academy of Religion 81(3):644-68.

Tisby, Jemar. 2019. The Color of Compromise: The Truth about the American Church's Complicity in Racism. Grand Rapids, Ml: Zondervan.

Tranby, Eric, and Douglas Hartmann. 2008. "Critical Whiteness Theories and the Evangelical 'Race Problem': Extending Emerson and Smith's 'Divided by Faith."' Journal for the Scientific Study of Religion 47(3):341-59.

Whitehead, Andrew L., Samuel L. Perry, and Joseph O. Baker. 2018. "Make America Christian Again: Christian Nationalism and Voting for Donald Trump in the 2016 Presidential Election." Sociology of Religion 79(2):147-71.

Wuthnow, Robert. 2011. "Taking Talk Seriously: Religious Discourse as Social Practice." Journal for the Scientific Study of Religion 50(1):1-21.

\section{Biographies}

Kelsy Burke is an assistant professor of sociology at the University of NebraskaLincoln, where she researches the intersection of white evangelicalism, gender, and heterosexuality within contemporary American culture and politics. Her first book is Christians under Covers: Evangelicals and Sexual Pleasure on the Internet (University of California Press, 2016). Twitter: @kelsyburke.

Amy McDowell is an assistant professor of sociology at the University of Mississippi, where she researches the intersection of religion, popular culture, race, gender, and sexuality. Her previous research has been published in Sociology of Religion, Gender \& Society, and the Sociology of Race \& Ethnicity. Twitter: @AmyD_McD. 